\title{
Виталий Анатольевич Пухальский: к 85-летию со дня рождения
}

Н.П. Гончаров ${ }^{1}$, Г.И. Карлов ${ }^{2}$, А.М. Кудрявцев ${ }^{3}$, В.П. Упелниек ${ }^{4}$, А.А. Соловьев ${ }^{2}$ ब

${ }^{1}$ Федеральный исследовательский центр Институт цитологии и генетики Сибирского отделения Российской академии наук, Новосибирск, Россия

2 Всероссийский научно-исследовательский институт сельскохозяйственной биотехнологии, Москва, Россия

${ }^{3}$ Институт общей генетики им. Н.И. Вавилова Российской академии наук, Москва, Россия

${ }^{4}$ Главный ботанический сад им. Н.В. Цицина Российской академии наук, Москва, Россия

\section{On the $85^{\text {th }}$ anniversary of Vitaliy A. Pukhalskiy}

N.P. Goncharov¹, G.I. Karlov², A.M. Kudryavtsev³, V.P. Upelniek ${ }^{4}$, A.A. Soloviev² ${ }^{2}$

${ }^{1}$ Institute of Cytology and Genetics SB RAS, Novosibirsk, Russia

${ }^{2}$ All-Russia Research Institute of Agricultural Biotechnology (ARRIAB), Moscow, Russia

${ }^{3}$ Vavilov Institute of General Genetics, Russian Academy of Sciences, Moscow, Russia

${ }^{4}$ Federal State Budgetary Institution of Sciences the Main Botanical Garden named after Tsitsin of Russian Academy of Sciences, Moscow, Russia

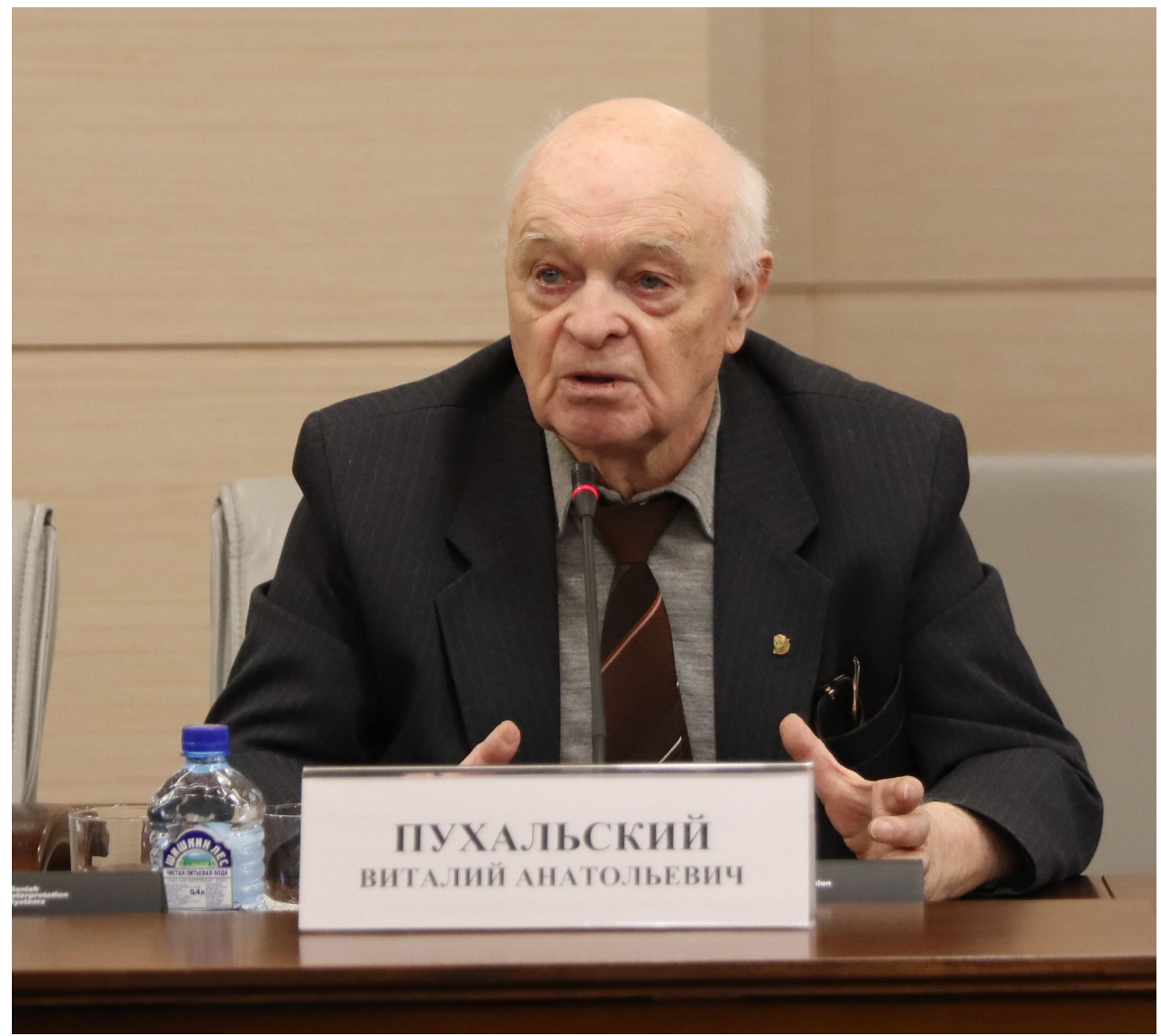

Виталий Анатольевич Пухальский

Источник: https://duma.mos.ru/ru/0/news/novosti-fraktsiy/timiryazevskaya-akademiya-doljna-vnov-statglavnyim-agrarnyim-vuzom-stranyi?tryMobile $=0$ 
Ведущий отечественный генетик и цитогенетик растений, доктор биологических наук, профессор Виталий Анатольевич Пухальский родился 9 ноября 1934 года в селе Подоплеки Фаленского района Кировской области (бывшая Вятская селекционная станция, ныне Фаленская ГСС) в семье селекционеров, аспирантов вавиловского Всесоюзного института растениеводства (Шумный, Гончаров, 2008).

Среднюю школу окончил в Москве и в 1952 году поступил в Московскую сельскохозяйственную академию им. К.А. Тимирязева, на отделение селекции и семеноводства, которую окончил с

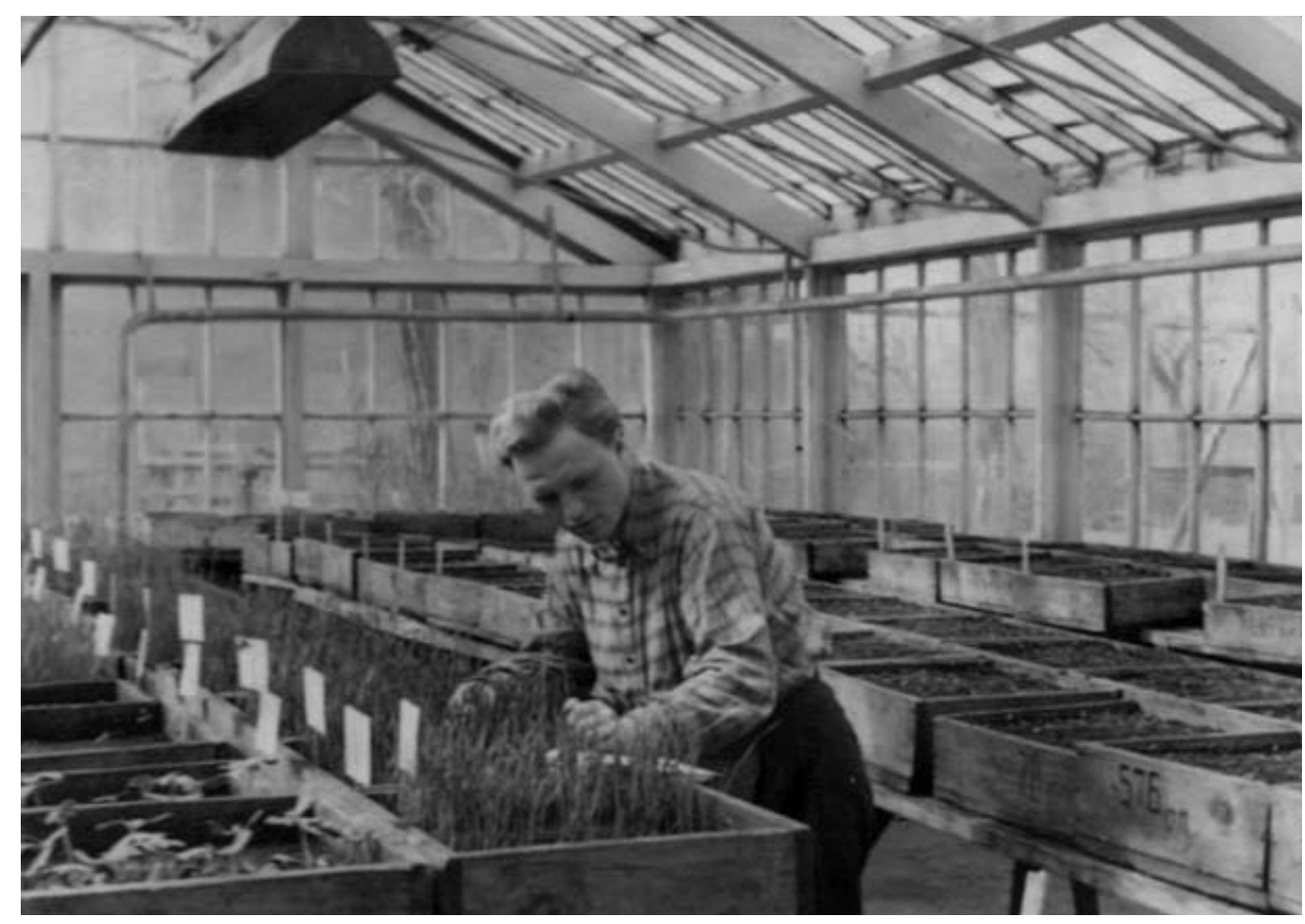

Аспирантура в ТСХА.

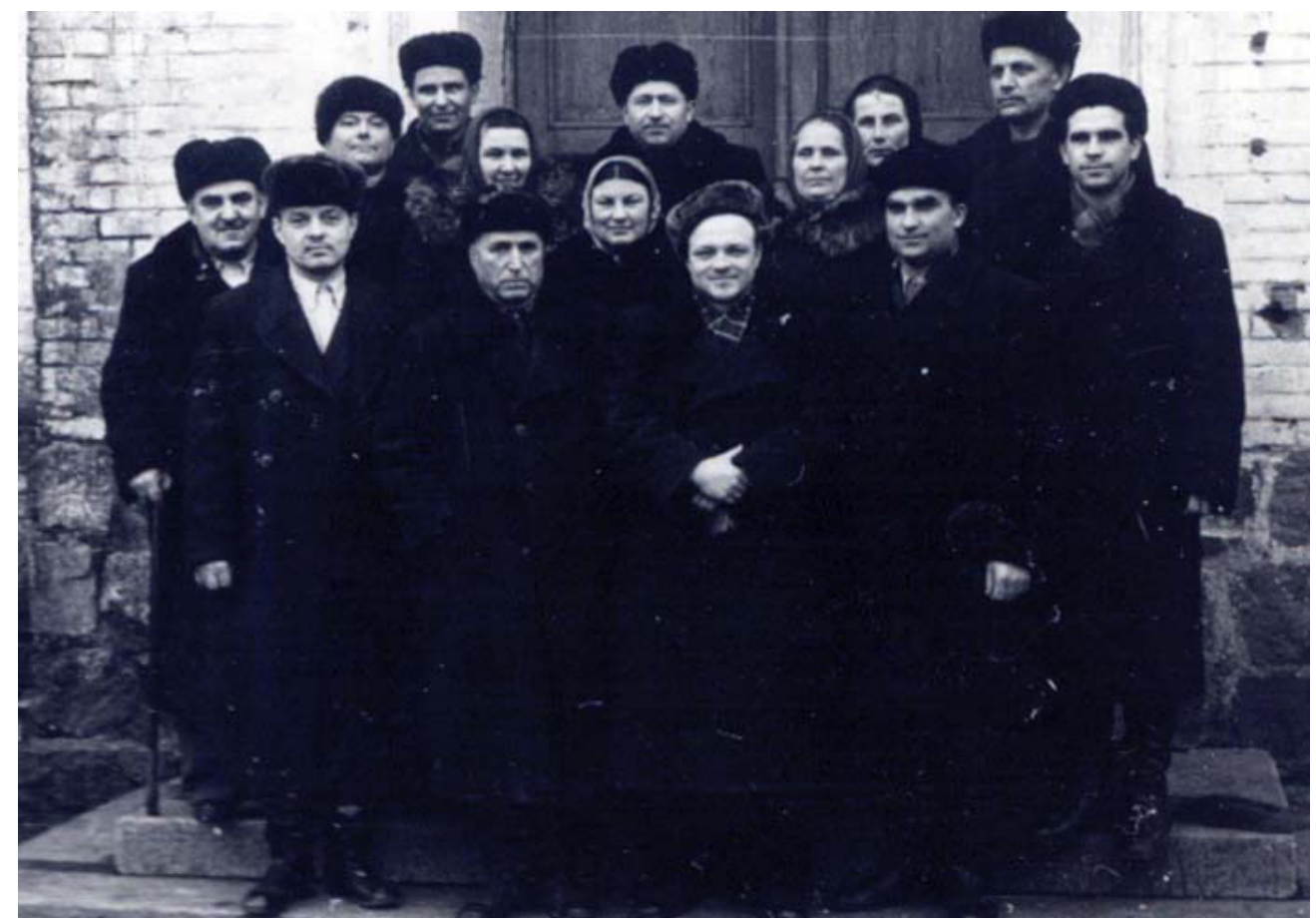

Мироновка перед отъездов в ТСХА. 


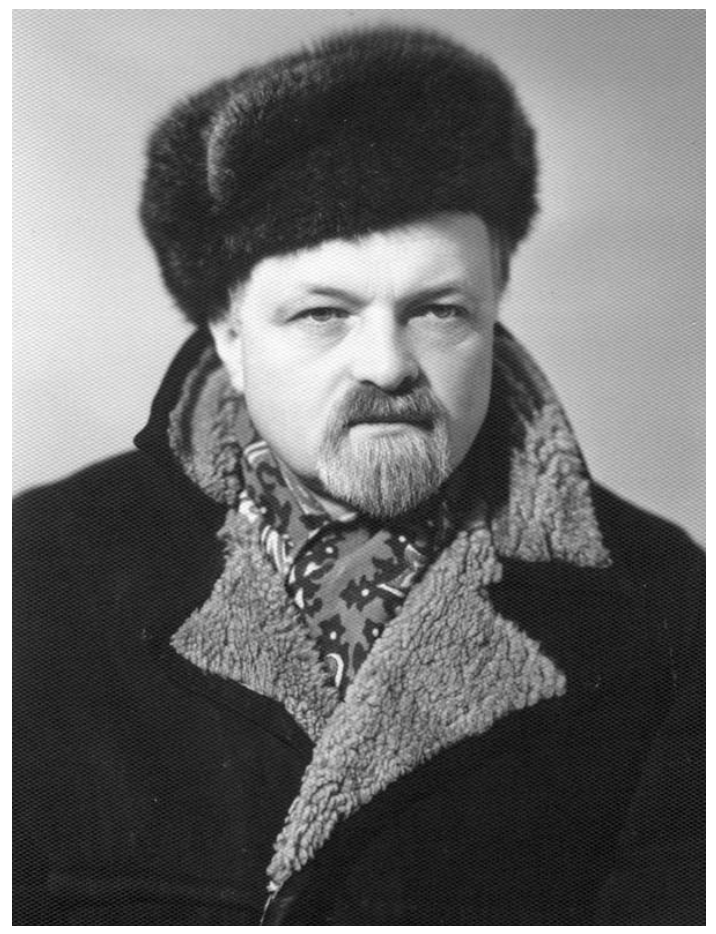

Доцент В.А. Пухальский.

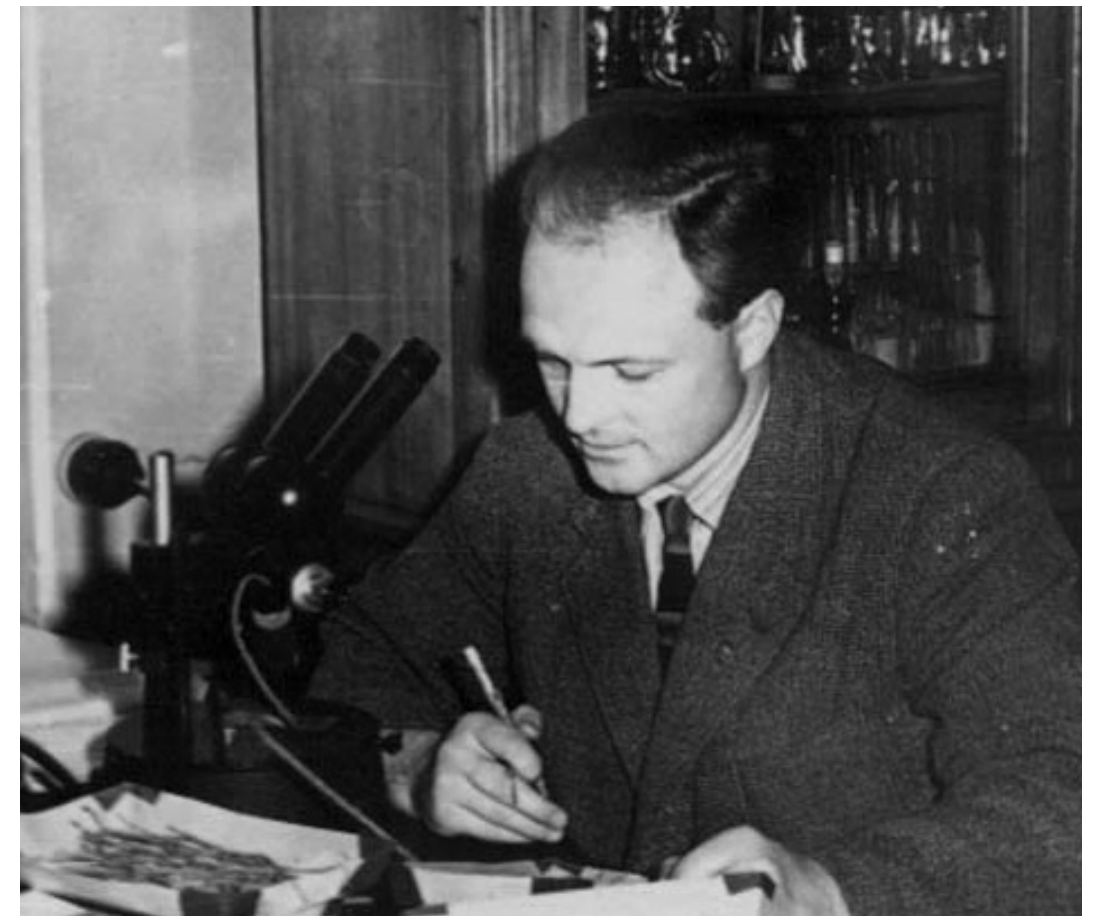

За бинокуляром.

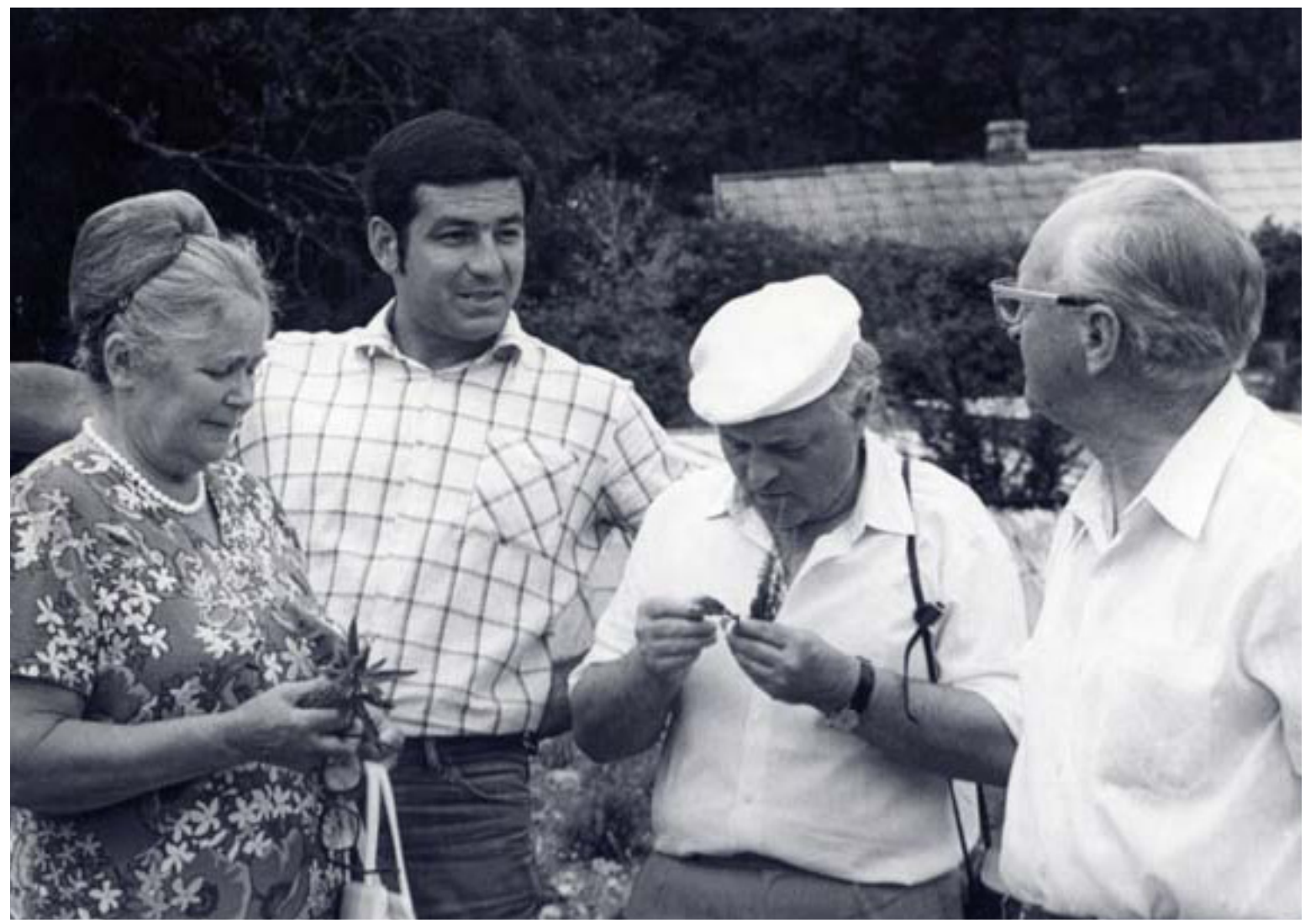

Никитский ботанический сад. 


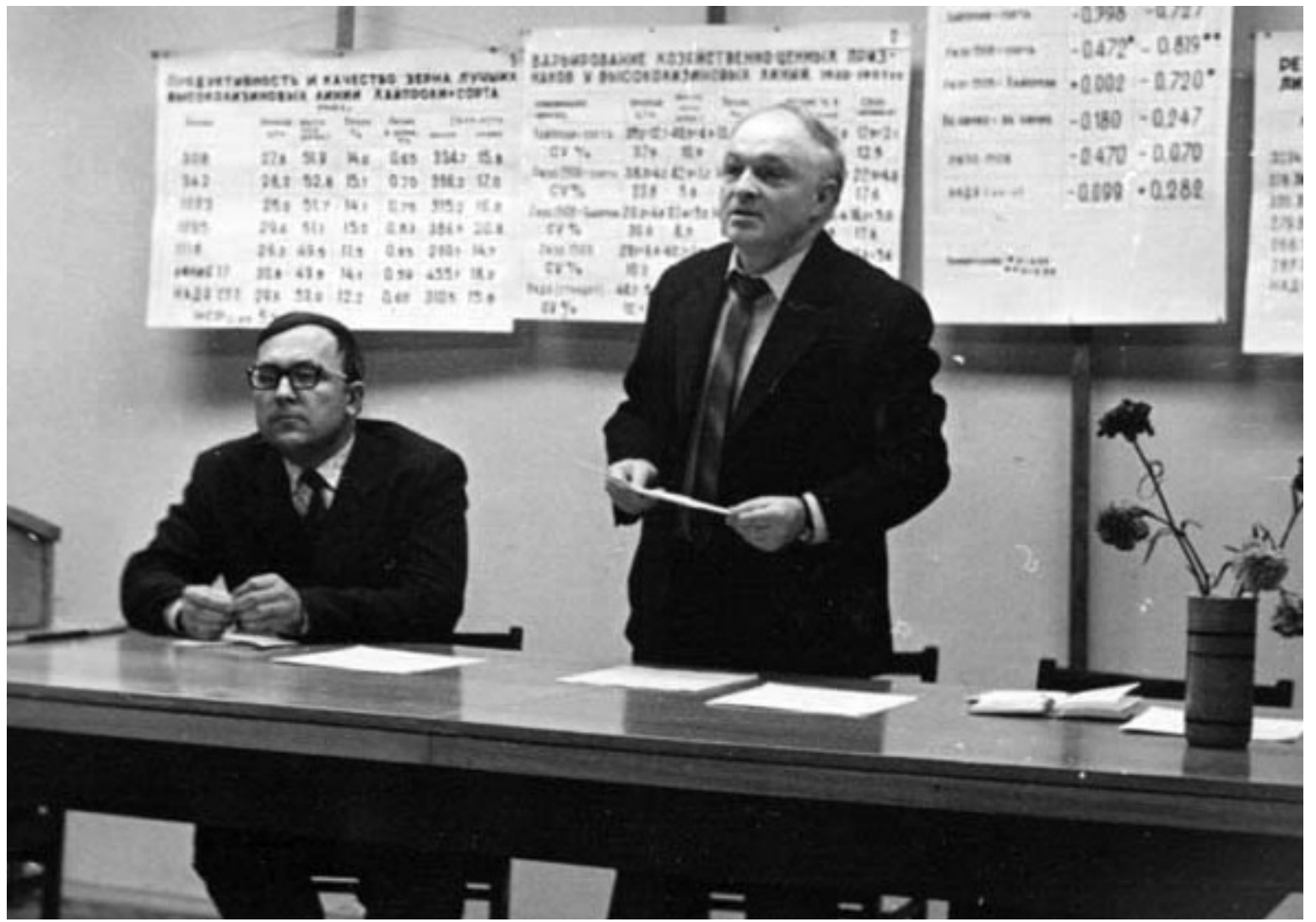

На конференции.

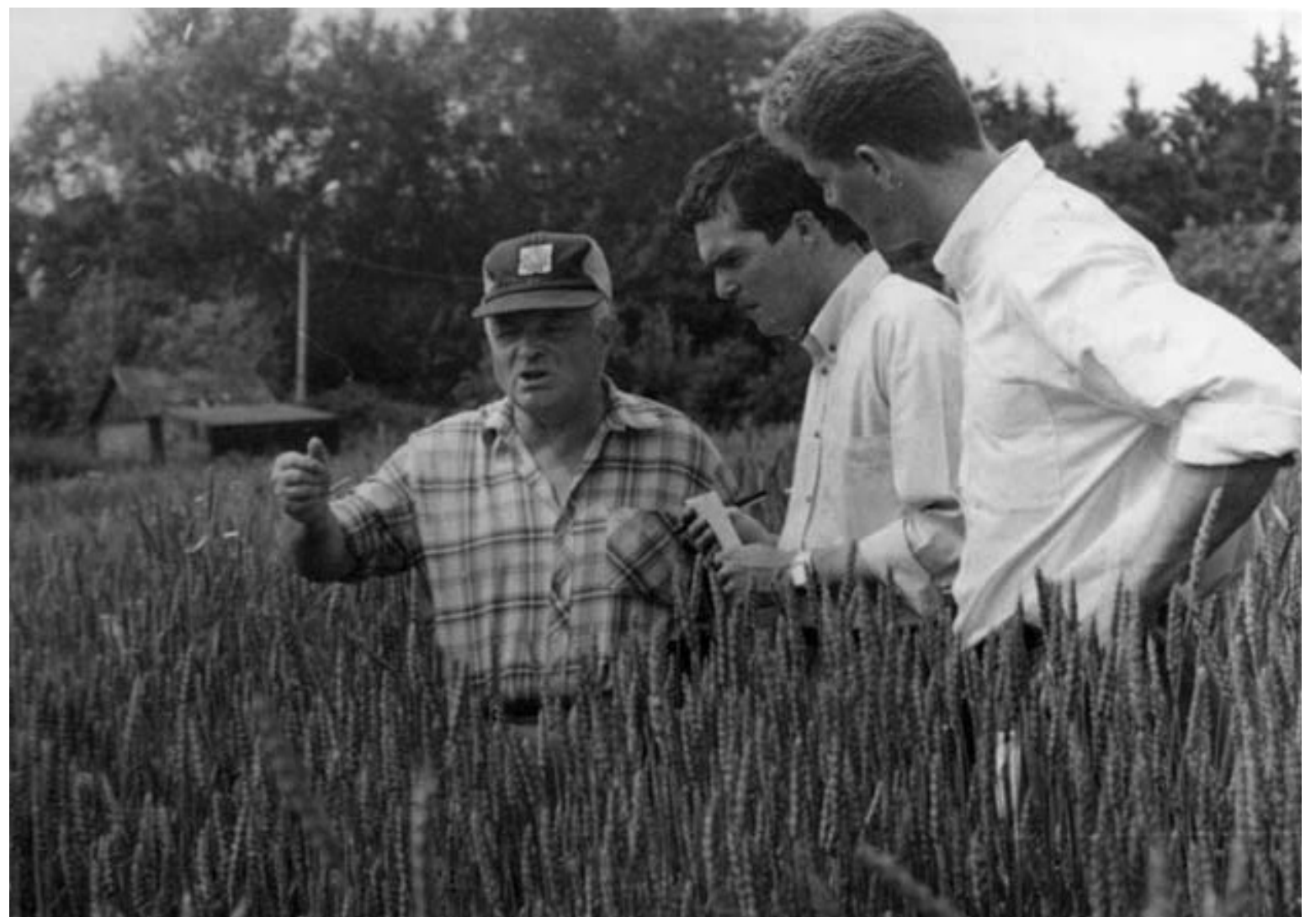




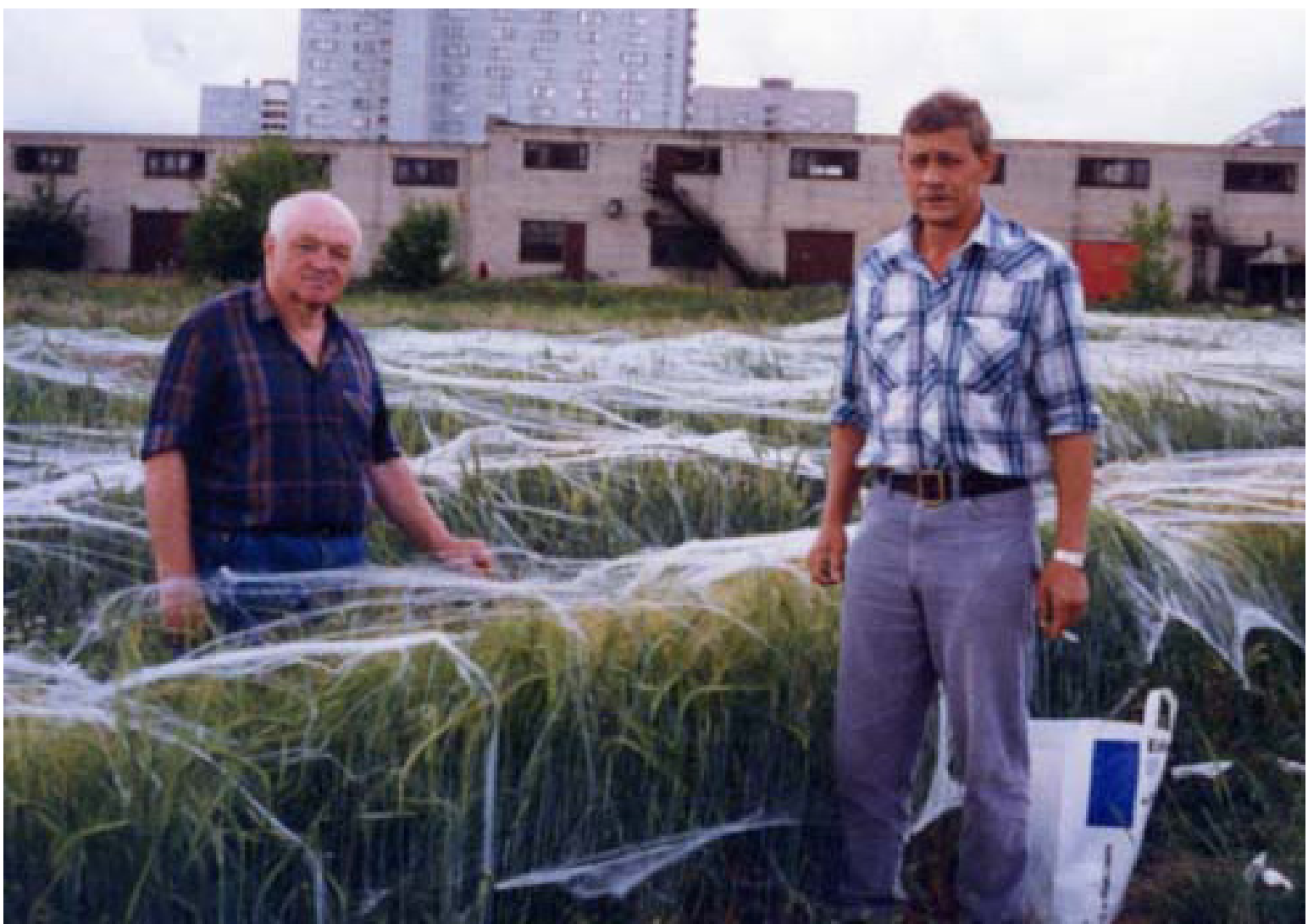

В Немчиновке.

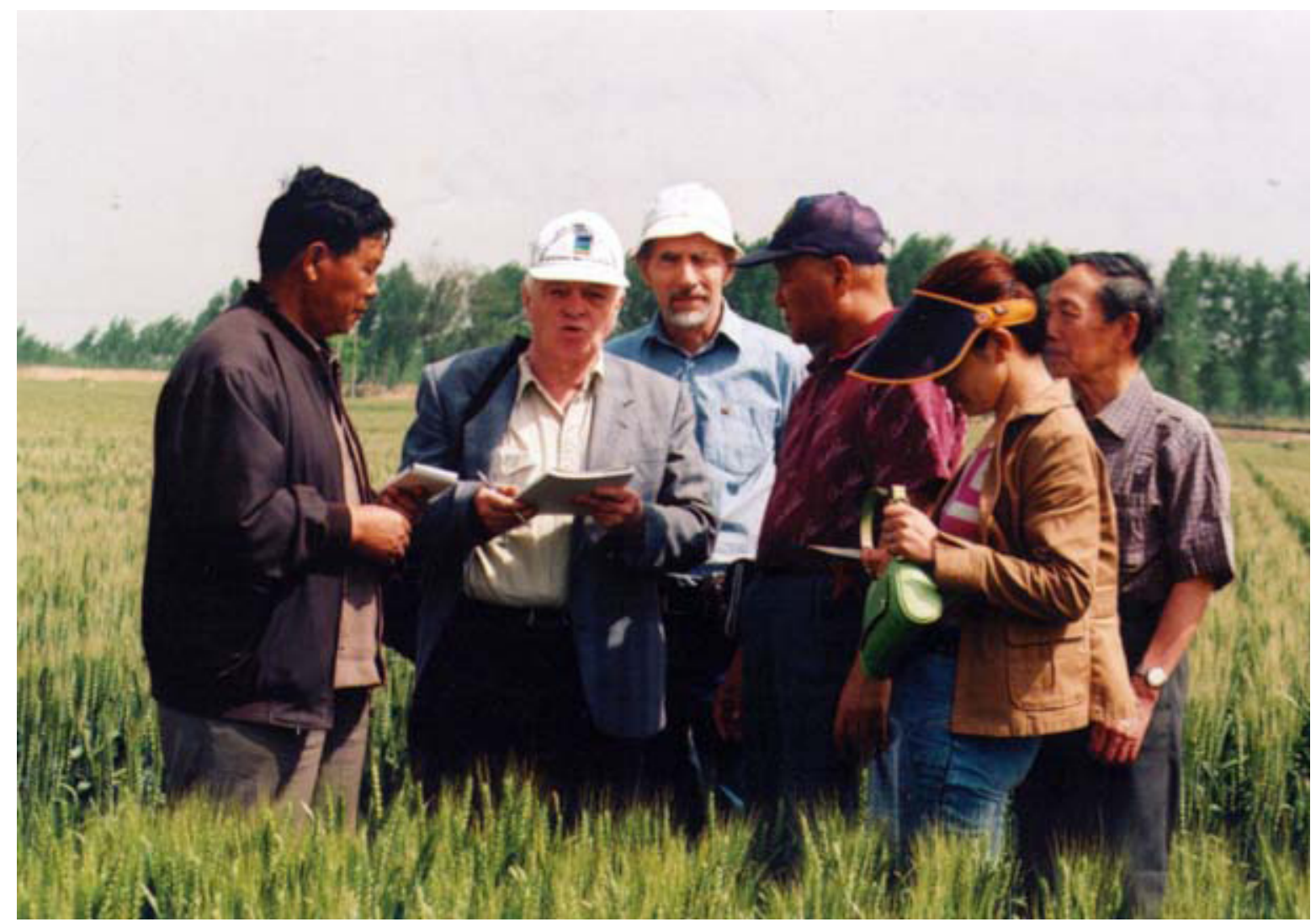

С коллегами КНР. 
отличием. После окончания академии в 1957 году был направлен на работу на Мироновскую селекционно-опытную станцию Всесоюзного института кукурузы (Киевская обл.), где работал сначала в качестве научного сотрудника по селекции пшеницы, а затем заведовал группой селекции зернобобовых культур.

В 1960 году В.А. Пухальский поступил в аспирантуру на кафедру генетики, селекции и семеноводства ТСХА, которую успешно окончил, защитив кандидатскую диссертацию на тему «Биология и морфогенез озимой твердой пшеницы». После защиты диссертации был оставлен на кафедре, где проработал в должности ассистента, а затем доцента до 1980 года. В этот период В.А. Пухальский проводил научные исследования в области цитогенетики и частной генетики пшеницы. Эти исследования были посвящены проблеме селективного оплодотворения у пшеницы и изучению генов летальности в роде Triticum L. Результаты исследований были обобщены в диссертации на соискание ученой степени доктора биологических наук на тему «Исследование генных систем, вызывающих летальность в роде Triticum L., применительно к генетической теории селекции». Диссертация была защищена в 1982 году в Институте общей генетики РАН. В этом же году ВАК присвоил ему ученую степень доктора биологических наук, а в 1983 году - профессора.

В 1969-1970 годах в течение 10 месяцев был на научной стажировке в итальянском Национальном Атомном Центре (Centro studi nucleari Casaccia, Santa Maria di Galeria), г. Рим.

Большой период жизни В.А. Пухальский посвятил научно-исследовательской работе в НИИСХ ЦРНЗ (Немчиновка, Московская обл.), в котором в 1980 году был избран на должность заведующего лабораторией генетики и цитологии и проработал до 1992 года. Научные интересы и исследования в этот период охватывали проблему оптимизации селекционного процесса пшеницы и ячменя на основе инконгруентных скрещиваний, применения генетических и цитологических маркеров и методов биотехнологии.

Одновременно в 1985 году В.А. Пухальский был приглашен в Институт общей генетики имени Н.И. Вавилова РАН (г. Москва) для заведования лабораторией генетических методов селекции, в дальнейшем лаборатория генетики растений. В 1992 году оставил работу в Немчиновке и полностью перешел на работу в Институт общей генетики РАН. Проводимые им исследования охватывают такие проблемы, как изучение генетических основ иммунитета растений к фитопатогенам, разработка подходов к получению трансгенных растений, создание системы генетических, биохимических, цитологических и молекулярных маркеров для сравнительного изучения генома, генетического разнообразия и филогении культурных растений и их сородичей.

На основе разработанной В.А. Пухальским методики в лаборатории с использованием агробактериальной трансформации впервые в России была получена трансгенная пшеница, что опровергает устоявшееся на тот момент мнение о неприменимости агробактериальной трансформации к однодольным. Одновременно им с сотрудниками получены растения табака и картофеля с рекомбинантным геном а-интерферона человека (1990-1996). Внедрение биотехнологических методов в селекционный процесс позволило впервые в России создать сорт ярового ячменя Биос-1, районированный в четырех регионах РФ. В.А. Пухальским с сотрудниками получены антивирусные растительные вакцины, с успехом применяемые в агрокомбинатах, и разработаны технологии их производства. Большой интерес представляют выпол- ненные работы по генетическому мониторингу пшеницы в связи с антропогенной деятельностью человека. Несомненно, что все эти вопросы имеют как фундаментальное, так и прикладное значение. Весомый вклад в развитие генетической теории селекции и применения генетических методов представлен в его научных публикациях - им опубликовано более 360 печатных работ, включая две монографии (обе в соавторстве).

С 1992 года В.А. Пухальский возобновил преподавательскую работу, став профессором кафедры генетики Московской сельскохозяйственной академии имени К.А. Тимирязева, в дальнейшем кафедры генетики и биотехнологии и кафедры генетики, биотехнологии, селекции и семеноводства. На протяжении более 20 лет он читал курс лекций по генетике для студентов агрономического и агрохимического факультетов, внедряя генетические знания в молодые студенческие умы. Лекции Виталия Анатольевича всегда привлекали не только студентов, но и аспирантов и сотрудников академии. Его опыт преподавательской работы отражен в учебных пособиях. В.А. Пухальский является автором и соавтором десяти учебных пособий для студентов агрономических специальностей, специализирующихся в области селекции и генетики сельскохозяйственных культур.

Большой вклад Виталий Анатольевич внес в подготовку кадров высшей квалификации. Под его руководством защищена 21 кандидатская. Он был консультантом шести докторских диссертаций.

Как крупный специалист в своей области В.А. Пухальский регулярно участвует в работе международных съездов, симпозиумов и совещаний. Его постоянно приглашают в экспертные комиссии. В разные годы В.А. Пухальский был членом экспертного совета ВАК (1993-2002), членом Научного совета Министерства науки и технологий РФ по подпрограмме «Перспективные процессы производства сельскохозяйственной продукции», членом Бюро отделения растениеводства РАСХН и диссертационных советов. Он также входил в состав редколлегии журнала «Генетика» и редакционного совета журнала «Селекция и семеноводство».

За свою большую и многогранную жизнь Виталий Анатольевич Пухальский сделал немало важных открытий, воспитал большое число учеников. В его славный юбилей от имени всех учеников и коллег мы сердечно поздравляем доктора биологических наук, профессора Виталия Анатольевича Пухальского и желаем крепкого здоровья, долгих лет жизни, творческих успехов и всего самого наилучшего.

\section{Библиографический указатель трудов А.В. Пухальского}

Учебники и учебные пособия

Иванова С.В., Долгодворова Л.И., Карябин Н.А., Пухальский В.А., Соловьев А.А. Рабочая тетрадь для лабораторно-практических занятий по цитологии и генетике. - М.: МСХА, 1996. - 19 с.

Иванова С.В., Долгодворова Л.И., Пухальский В.А., Смиряев А.В., Соловьев А.А. Задачник по генетике. - М.: МСХА, 1996. - 78 С.

Наумов А.А., Пухальский В.А. Селекция пшеницы (учебное пособие). - М., 1984. -47 c.

Пухальский В.А. Частная селекция полевых культур (ч. І. Пшеница, кукуруза). - М.: TCXA, 1972. - 89 c.

Пухальский В.А. Кукуруза. В кн. Частная селекция полевых культур. - М.: Колос, 1975. - С. 159-199.

Пухальский В.А. Пшеница. В кн. Частная селекция полевых культур. - М.: Колос, 1975. - С. 9-55.

Пухальский В.А. Менделизм. Принципы и методы генетического анализа. Генетика. - М.: КолосС, 2003. 
Пухальский В.А. Цитологические основы наследственности. Генетика. - М.: КолосС, 2003.

Пухальский В.А. Введение в генетику. - М.: МСХА, 2004.

Пухальский В.А. Введение в генетику. - М.: КолосС, 2007. - 223 С.

Пухальский В.А. Введение в генетику. - М.: ИНФРА-М, 2014. - 224 с.

Пухальский В.А., Зеленов А.Н. Горох: В кн. Частная селекция полевых культур. - М.: Колос, 1975. - С. 227-242.

Пухальский В.А., Иванова С.В. Рис: В кн. Частная селекция полевых культур, - М.: Колос, 1975. - С. 140-158.

Пухальский В.А., Иванова С.В., Степанова Л.В. Тетрадь для лабораторных работ по курсу «Цитология растений». - М.: ТСХА, 1978. - 39 с.

Пухальский В.А., Иванова С.В., Степанова Л.В. Тетрадь для лабораторных работ по курсу «Цитология растений». - М.: ТСХА, 1982. - 39 с.

Пухальский В.А., Соловьев А.А., Юрцев В.Н. Цитология и цитогенетика растений. - М.: МСХА, 2004.

Пухальский В.А., Соловьев А.А., Бадаева Е.Д., Юрцев В.Н. Практикум по цитологии и цитогенетике растений. - М.: КолосС, 2007.

Юрцев В.Н., Пухальский В.А. Методическое руководство к лабораторным практическим занятиям по цитологической и эмбриологической микротехнике. - М.: TCXА, 1968. - 113 с.

\section{Монографии и научные издания}

Алтухов Ю.П., Захаров-Гезихус И.А., Пухальский В.А. и др. Динамика популяций генофондов при антропогенных воздействиях. - М.: Наука, 2004. - 619 c.

Коваленко Е.Д., Коломиец Т.М., Киселева М.И., Соломатин Д.А., Родина Н.А., Пухальский В.А., Руденко М.И. Рекомендации по использованию сортообразцов ячменя в качестве исходного материала в селекции сортов, устойчивых к наиболее вредоносным возбудителям болезней. - М., 1999. $-28 \mathrm{C}$

Мережко А.Ф., Пухальский В.А., Писарева Л.А. Прилюк А.В. Морфологические признаки пшеницы. Коллективная монография «Генетика культурных растений. Зерновые культуры». - Л.: Агропромиздат, 1986.

Пухальский В.А. Научные исследования в области генетики и селекции пшеницы в Италии. Изд. ВИНИТИСХ МСХ СССР. - М., 1973. - 64 с.

Пухальский В.А., Мартынов С.П., Добротворская Т.В. Гены гибридного некроза пшениц: Теория вопроса и каталог носителей летальных генов / РАН. Ин-т общ. генетики им. Н.И. Вавилова. - М.: МСХА, 2002. - 316 с.

Гончаров Н.П., Вишнякова М.А., Котелкина И.В., Лассан Т.К. Георгий Дмитриевич Карпеченко [Известный специалист в области генетики и отдаленной гибридизации с.-х. культур, сподвижник Вавилова Н.И.] / Н.П. Гончаров [и др.]; отв. ред. В.А. Пухальский. Российская академия наук, Сибирское отделение, Институт цитологии и генетики, Рос. акад. c.-х. наук, Всероссийский научно-исследовательский институт растениеводства им. Н. И. Вавилова. - 3-е изд., испр. и доп. - Новосибирск: Изд-во СО РАН, 2013. - 252 с.

\section{Научные статьи}

Бадаев Н.С., Амосова А.В., Пухальский В.А., Зеленин А.В. Изменение Agокрашивания ядрышкообразующих районов у межсортовых гибридов ячменя. Генетика. 1994. Т. 30. № 11. С. 1507-1512.

Бадаева Е.Д., Будашкина Е.Б., Билинская Е.Н., Пухальский В.А. Закономерности межгеномных замещений хромосом у межвидовых гибридов пшеницы и их использование для создания генетической номенклатуры хромосом Triticum timopheevii. Генетика. 2010. T. 46. № 7. C. 869-886.

Бадаева Е.Д., Дедкова О.С., Пухальский В.А., Зеленин А.В. Сравнительное цитогенетическое исследование видов Aegilops L., содержащих N-геном. Генетика. 2012. Т. 48. № 5. С. 617-627.

Бадаева Е.Д., Лоскутов И.Г., Шелухина О.Ю., Пухальский В.А. Цитогенетическое исследование диплоидных видов рода Avena L., содержащих Asгеном. Генетика. 2005. Т. 41. № 12. С. 1718-1724.

Бадаева Е.Д., Прокофьева З.Д., Билинская Е.Н., Оболенкова Л.А., Соломатин Д.А., Зеленин А.В., Пухальский В.А. Цитогенетический анализ устойчивых к бурой ржавчине и мучнистой росе гибридов, полученных от скрещивания мягкой пшеницы (Triticum aestivum, AABBDD) с пшеницами группы Timopheevi (AtAtGG). Генетика. 2000. Т. 36. № 12. С. 1663-1673.

Бадаева Е.Д., Раунет В.В., Дедкова О.С., Митрофанова О.П., Зеленин А.В., Пухальский В.А. Использование искусственных нейронных сетей для анализа внутривидовой дивергенции гексаплоидной пшеницы Triticum spelta L. на основании рисунков дифференциального окрашивания хромосом. Биологические мембраны. 2005. Т. 22. № 3.
Бадаева Е.Д., Шелухина О.Ю., Дедкова О.С., Лоскутов И.Г., Пухальский В.А. Сравнительное цитогенетическое исследование гексаплоидных видов Avena L. [Исследование изменений кариотипа в процессе эволюции]. Генетика. 2011. Т. 47. № 6. С. 783-795.

Билинская Е.Н., Мартынов С.П., Оболенкова Л.А., Драгович А.Ю., Пухальский В.А. Исследование генома культурных растений и их сородичей применительно к генетической теории селекции: генотипы по генам гибридного некроза сортов озимой мягкой пшеницы Сербии. Динамика генофондов. - М., 2008. - С. 190-191.

Брежнева Т.А., Упелниек В.П., Пухальский В.А. Генетический контроль компонентов глиадина у вида пшеницы Triticum spelta L. Генетика. 2010. Т. 46. № 5. С. 640-644.

Вареница Е.Т., Пухальский В.А. Селекция озимой пшеницы в Италии. Сельское хозяйство за рубежом (растениеводство). 1968. № 4. С.25-31.

Гинс В.К., Пискунова Н.П, Мутускин А.А., Пухальский В.А., Мухин Е.Н. / Светозависимое восстановление НАДФ в хлоропластах и активность гликолатоксидазы у яровых пшениц разной продуктивности в онтогенезе. Физиология растений. 1985. Т. 32. Вып. 1. С. 53-60.

Гинс В.К., Пискунова Н.П., Лысенко Г.Г., Пухальский В.А., Мухин Е.Н. Фотовосстановление НАДФ и кислорода в хлоропластах листа яровой пшеницы в фазах кущения и выхода в трубку. Физиология растений. 1987. Т. 34. Вып. 3. С. 461-468.

Гинс В.К., Пискунова Н.П., Макарова И.Ю, Пухальский В.А. Теплоустойчивость фотосистемы II хлоропластов сортов ярового ячменя. Сельскохозяйственная биология. 1993. № 5. С. 90-94.

Гинс В.К., Пискунова Н.П., Хомутова Г.К., Тихонов А.Н., Мухин Е.Н., Пухальский В.А. Динамика содержания реакционных центров фотосинтеза I (р700) и их фотовосстановительной активности в онтогенезе сортов яровой пшеницы. Физиология растений. 1986. Т. 33. Вып. 5. С. 904-912.

Гинс В.К., Пухальский В.А., Мухин Е.Б. Эффективность работы электротранспортной цепи хлоропластов пшеницы при различных температурах в связи с проявлением гибридного некроза. Доклады ВАСХНИЛ. 1981. № 6. C. 7-9.

Горюнова С.В., Бадаева Е.Д., Лоскутов И.Г., Пухальский В.А. Молекулярная филогения рода Avena L.: Материалы XII Московского совещания по филогении растений, посвященного 250-летию со дня рождения Георга-Франца Гофмана. - М., 2010. - С. 123-126.

Горюнова С.В., Кочиева Е.3., Чикида Н.Н., Пухальский В.A. RAPD-анализ внутривидовой изменчивости и филогенетических связей видов эгилопса (Aegilops), содержащих геном D. Генетика. 2004. T. 40. № 5. C. 642-651.

Горюнова С.В., Чикида Н.Н., Бадаева Е.Д., Пухальский В.А. Полиморфизм и филогения D-геномных видов Aegilops L. по данным анализа микросателлитных локусов хлоропластного генома. Вестник МГУ (серия Биология). 2010. Т. 65. № 4. С. 21-24.

Дедкова О.С., Бадаева Е.Д., Амосова А.В., Мартынов С.П., Раунет В.В., Митрофанова О.П., Пухальский В.А. Разнообразие и происхождение европейской популяции Triticum dicoccum (Schrank) Schuebl. на основании хромосомного анализа. Генетика. 2009. Т. 45. № 9. С. 1234-1243.

Дедкова О.С., Бадаева Е.Д., Митрофанова О.П., Билинская Е.Н., Пухальский В.А. Исследование внутривидового разнообразия тетраплоидной пшеницы Triticum dicoccum (Schrank.) Schuebl с помощью метода дифференциального окрашивания хромосом. Генетика. 2007. Т. 43. № 11. C. 1517-1533.

Дедкова О.С., Бадаева Е.Д., Митрофанова О.П., Зеленин А.В., Пухальский В.А. Анализ внутривидовой дивергенции гексаплоидной пшеницы Triticum spelta L. с помощью метода дифференциального окрашивания хромосом. Генетика. 2004. Т. 40, № 10. С. 1352-1369.

Джорджи Б., Пухальский В.А., Саккардо А. Изучение дицентрических хромосом у некоторых видов тетраплоидных пшениц. Известия ТСХА. 1972. Вып. 5. С. 63-67.

Добротворская Т.В., Драгович А.Ю., Мартынов С.П., Пухальский В.А. Генеалогический и статистический анализ наследования аллелей глиадинкодирующих локусов в модельном наборе сортов мягкой пшеницы. Генетика. 2009. Т. 45. № 6. С. 781-792.

Добротворская Т.В., Мартынов С.П., Пухальский В.А. Анализ происхождения генов гибридного некроза у российских сортов мягкой пшеницы. Генетика. 1998. Т. 34. № 10 С.1359-1367.

Добротворская Т.В., Мартынов С.П., Пухальский В.А. Тенденции изменения генетического разнообразия сортов яровой мягкой пшеницы, районированных на территории России в 1929-2003 гг. Генетика. 2004. Т. 40. № 11. С. 1509-1522. 
Драгович А.Ю., Зима В.Г., Фисенко А.В., Беспалова Л.А., Букреева Г.И., Мельникова Е.Е., Щипкова Н.И., Пухальский В.А. Сопоставление двух существующих каталогов аллелей глиадинкодирующих локусов у озимой мягкой пшеницы. Генетика. 2006. Т. 42. № 8. С. 1107-1116.

Иванова С.В., Пухальский В.А., Ронис Н.Б. О нарушениях мейоза у пентаплоидных гибридов пшеницы. Сельскохозяйственная биология. 1979. Т. 14, № 5, С. 577-581.

Извекова Л.И., Андреева Э.Н., Вострова Н.Г., Фетисов А.В., Пухальский В.А. Штаммы вирусов для вакцинации растений: Фундаментальные науки народному хозяйству. - М.: Наука, 1990.

Извекова Л.И., Подъяпольская Т.С., Андреева Э.Н., Вострова Н.Г., Квасников Б.В., Игнатова С.И., Горшкова Н.С., Пухальский В.А. Селекция томата на устойчивость к ВТМ. Плодоовощное хозяйство. 1987. № 3. С. 47-50.

Извекова Л.И., Подъяпольская Т.С., Андреева Э.Н., Вострова Н.Г., Пухальский В.А., Квасников Б.В., Игнатова С.И., Горшкова Н.С. Вариабельность ВТМ и ее роль в селекции томата на устойчивость. Плодоовощное хозяйство. 1987. № 2. С. 28-30.

Извекова Л.И., Подъяпольская Т.С., Андреева Э.Н., Пухальский В.А., Вострова Н.Г., Квасников Б.В., Игнатова С.И., Горшкова Н.С. Вариабильность ВТМ и ее роль в селекции томатов на устойчивость. Плодоовощное хозяйство. 1987. № 1.

Истомина Е.А., Андреева Э.Н., Славохотова А.А., Коростылева Т.В., Шиян А.Н., Пухальский В.А. Вакцинация - эффективный способ защиты растений. Гавриш. 2014. № 4. С. 41-45.

Истомина Е.А., Коростылева Т.В., Конопкин А.А., Шиян А.Н., Коротцева И.Б., Пухальский В.А., Одинцова Т.И. Защита огурца от вирусной инфекции [Использование вакцины ВИРОГ-43М в борьбе с вирусом зеленой крапчатой мозаики огурца]. Гавриш. 2016. № 6. С. 56-61.

Истомина Е.А., Коростылева Т.В., Рожнова Н.А., Рогожин Е.А., Пухальский В.А., Одинцова Т.И. Гены гевеиноподобных антимикробных пептидов семейства WAMP пшеницы: экспрессия в ответ на действие фитогормонов и факторов внешней среды [Опыты на проростках гексаплоидной пшеницы Triticum kiharae]. Генетика. 2016. Т. 52. № 11. С. 1300-1310.

Истомина Е.А., Славохотова А.А., Коростылева Т.В., Семина Ю.В., Щербакова Л.А., Пухальский В.А., Одинцова Т.И. Гены гевеиноподобных антимикробных пептидов семейства WAMP у видов рода Aegilops. Генетика. 2017. T. 53. № 12. С. 1402-1410.

Коваленко Е.Д., Киселева М.И., Соломатин Д.А., Родина Н.А., Пухальский В.А., Руденко М.И. Исходный материал ячменя для селекции сортов с устойчивостью к основным возбудителям болезней. Агрохимия. 2002. № 4. С. 78-80.

Коваленко Е.Д., Киселева М.И., Соломатин Д.А., Руденко М.И., Пухальский В.А. Об устойчивости сортов ячменя к сетчатой пятнистости. $\mathrm{Ce}$ лекция и семеноводство. 2001. № 1-2. С. 57-59.

Козленко Л.В., Пухальский В.А. Продуктивность гибридов первого и второго поколений от межсортовых скрещиваний мягкой яровой пшеницы. Известия ТСХА. 1970. № 4. С. 86-91.

Козленко Л.В., Пухальский В.А. Проявление гетерозиса у мягкой яровой пшеницы (T. aestivum L.). Известия ТСХА. 1969. Вып. 1. С. 183-186.

Коломиец Т.М., Коваленко Е.Д., Стрижекозин Ю.А., Руденко М.И., Пухальский В.А. Изучение параметров частичной устойчивости сортов ячменя к возбудителям темно-бурой и сетчатой пятнистости [Фитопатологические критерии для отбора сортов с длительной устойчивостью]. Микология и фитопатология. 1998. Т. 32. № 4. С. 42-46.

Коростылева Т.В., Одинцова Т.И., Козловская Г.В., Пухальский В.А. Исследование белков листьев в трансгенных растениях табака, экспрессирующих двунитевую РНК при вирусной инфекции. Генетика. 2004. Т. 40. № 4. С. 531-537.

Кочиева Е.З., Рыжова Н.Н., Храпалова И.А., Пухальский В.А. Использование метода RAPD-анализа в определении генетического полиморфизма и филогенетических связей у представителей рода Lycopersicon (Tourn) Mill. Генетика. 2002. T. 38, № 9. С. 1298-1303.

Кочиева Е.З., Рыжова Н.Н., Храпалова И.А., Пухальский В.А. Определение генетического полиморфизма и филогенетических связей у представителей рода Lycopersicon (Tourn.) Mill методом маркирования межмикросателитных последовательностей (ISSR). Генетика. 2002. T. 38. № 8. С. $1133-1142$.

Кудрявцев А.М., Мартынов С.П., Броджио М., Пухальский В.А. Оценка правомерности использования RAPD-анализа для выявления филогенетических связей между сортами яровой твердой пшеницы (T. durum Desf.). Генетика. 2003. Т. 39. № 9. С. 1237-1246.

Куравамвели Д.С., Пухальский В.А. Деполиплоидизация мягкой пшеницы. Сельское хозяйство за рубежом. 1982. № 1. С. 23-27.
Лапочкина И.Ф, Пухальский В.А. Изучение мейоза у межвидовых гибридов T. spelta $\times$ T. durum. Цитология и генетика. 1983. Т. 17. № 5. С. 3-8.

Лапочкина И.Ф., Пухальский В.А. Влияние генотипа Aegilops speltoides Tansch. на характер конъюгации хромосом у гибридов, полученных с участием Т. aestivum. Цитология и генетика. 1989. Т. 23, № 3. С. 24-29.

Лапочкина И.Ф., Пухальский В.А. Влияние облученной пыльцы отцовского компонента на уровень конъюгации хромосом у гибридов $\mathrm{F}_{1}$ T. aestivum × T. kiharae. Известия СО АН СССР. 1990. Вып. 2. С. 31-32.

Лапочкина И.Ф., Ронис Н.Б., Пухальский В.А. Мейоз и стабилизация микроспорогенеза у межвидовых тетраплоидных гибридов T. spelta $\times$ T. aestivum. Сельскохозяйственная биология. 1984. № 8. С. 53-56.

Лапочкина И.Ф., Соломатин Д.А., Сережкина Г.В., Гришина Е.Е., Вишнякова Х.С., Пухальский В.А. Линии мягкой пшеницы с генетическим материалом Aegilops speltoides Tausch. [Получение гибридов, оценка их устойчивости к грибным болезням, цитогенетический анализ]. Генетика. 1996. Т. 32. № 12. С. 1651-1656.

Мальченко В.В., Иорданская И.В., Пухальский В.А. Генетическая характеристика сортов озимой пшеницы селекции НПО «Подмосковье»: Сб. «Совершенствование селекционно-генетических процессов при выведении сортов зерновых и зернобобовых культур в Нечерноземной зоне». - М., 1990

Мальченко В.В., Пухальский В.А., Кызласов В.Г., Руденко М.И., Латыпов А.З., Иорданская И.В., Марченко И.В. Генетика высоты растений зерновых культур в системе диаллельных скрещиваний: Сб. «Селекция зерновых культур на стабильность урожайности, иммунитета и качество зерна в Нечерноземной зоне». - М., 1986. - С. 113-124.

Мартынов С.П., Добротворская Т.В., Пухальский В.А. Анализ генетического разнообразия сортов яровой твердой пшеницы (Triticum durum Desf.), районированных на территории России в 1929-2004 гг. Генетика. 2005. Т. 41. № 10. С. 1358-1368.

Мартынов С.П., Добротворская Т.В., Пухальский В.А. Динамика генетического разнообразия сортов озимой мягкой пшеницы (Triticum aestivum L.), районированных на территории России в 1929-2005 гг. Генетика. 2006. Т. 42. № 10. С. 1359-1370.

Могутова О.Б., Денисова Л.В., Лазарева Е.Н., Пухальский В.А., Смолин В.П. Донорские свойства высоколизиновых мутантов ячменя и выделение перспективных форм с повышенным содержанием белка и лизина в зерне. Сельскохозяйственная биология. 1986. № 9. С. 15-18.

Муравенко О.В., Бадаев Н.С., Бадаева Е.Д., Пухальский В.А., Зеленин А.В. Идентификация хромосом ячменя в соответствии с генетической номенклатурой хромосом пшеницы. Доклады АН СССР. 1986. № 3. С. $724-$ 727.

Муравенко О.В., Бадаев Н.С., Руденко М.И., Пухальский В.А., Зеленин А.В. Закономерности становления и организации генома злаков. Сообщение II. Хромосомный полиморфизм межсортовых гибридов ячменя. Генетика. 1990. Т. 26. № 6. С. 1070-1078.

Муравенко О.В., Руденко М.И., Оноприенко В.С., Пухальский В.А., Зеленин А.В. Количественный анализ хромосомного полиморфизма ячменя. Генетика. 1986. Т. 22. № 12. С. 2831-2838.

Неттевич Э.Д., Молчанова Л.М., Чистякова В.Н., Пухальский В.А., Смолин В.П., Денисова Л.В., Внучкова В.А. Гаплоидия как метод создания исходного материала в селекции. Вестник сельскохозяйственной науки. 1989. № 7. С. 93-99.

Николаев А.А., Пухальский В.А., Упелниек В.П. Генетическое разнообразие местных яровых пшениц (Triticum aestivum L.) Западной и Восточной Сибири по генам глиадинов. Генетика. 2009. Т. 45. № 2. С. 215-224.

Новосельская-Драгович А.Ю., Фисенко А.В., Имашева А.Г., Пухальский В.А. Сравнительный анализ динамики генетического разнообразия по глиадинкодирующим локусам среди сортов озимой мягкой пшеницы Triticum atstivum L., созданных за 40-летний период научной селекции в Сербии и Италии. Генетика. 2007. Т. 43. № 11. С. 1478-1485.

Новосельская-Драгович А.Ю., Крупнов В.А., Сайфулин Р.А., Пухальский В.А. Динамика генетического разнообразия саратовских сортов мягкой пшеницы Triticum aestivum L. (по глиадинкодирующим локусам) за 80-летний период научной селекции. Генетика. 2003. Т. 39. № 10. С. $1338-1346$.

Новосельская-Драгович А.Ю., Фисенко А.В., Пухальский В.А. Генетическая дифференциация сортов мягкой пшеницы с использованием множественных глиадинкодирующих локусов. Генетика. 2013. Т. 49. № 5. С. 569-579.

Одинцова Т.И., Андреева Э.Н., Пухальский В.А., Мусолямов А.Х., Егоров Ц.А. Структурный анализ белка оболочки вируса зеленой крапчатой мозаики огурца. Биохимия. 2000. Т. 65. Вып. 5. С. 672-679. 
Одинцова Т.И., Васильева И.М., Коростылева Т.В., Уткина Л.Л., Славохотова А.А., Рогожин Е.А., Шиян А.А., Пухальский В.А., Засухина Г.Д. Антимутагенная активность $\beta$-пуротионина Tk-AMP-BP пшеницы. Генетика. 2011. T. 47. № 9. С. 1267-1270.

Одинцова Т.И., Коростылева Т.В., Славохотова А.А., Андреева Э.Н., Пухальский В.А. Исследование генома культурных растений и их сородичей применительно к генетической теории селекции: исследование структуры гевеиноподобных антимикробных пептидов семян Triticum kicharae и кодирующих генов для выяснения их роли во врожденном иммунитете растений. Динамика генофондов. - М., 2008. С. $183-186$.

Одинцова Т.И., Коростылева Т.И., Уткина Л.Л., Андреев А.А., Славохотова А.А., Истомина ЕА., Пухальский В.А., Егоров Ц.А. Антимикробные пептиды пшеницы [На примере Triticum kiharae]. Вавиловский журнал генетики и селекции. 2012. Т. 16. № 1. С. 107-115.

Одинцова Т.И., Турищева М.П., Андреева Э.Н., Пухальский В.А. Структурнофункциональные изменения в хлоропластах томатов с разными генами устойчивости к вирусу табачной мозаики при заражении вирусом. Генетика. 1996. Т. 32. № 11. С. 1545-1552.

Одинцова Т.И., Фетисов А.В., Андреева Э.Н., Извекова Л.И., Егоров Ц.А., Пухальский В.А. Структурные исследования белка оболочки вируса зеленой крапчатой мозаики огурца. Доклады РАСХН. 1996. № 6. С. 26-28.

Одинцова Т.И., Янаудите Р.Л., Егоров Ц.А., Извекова Л.И., Андреева Э.Н., Пухальский В.А. Обнаружение интерфероноподобных белков в листьях томатов. Доклады АН СССР (Биохимия). 1990. Т. 314. № 5. С. 1250-1252.

Одинцова Т.И., Янаудите Р.Л., Егоров Ц.А., Извекова Л.И., Андреева Э.Н., Пухальский В.А. Белки томатов при инфекции ВТМ. Доклады АН СССР. 1990. Т. 313. № 3. С. $733-736$.

Одинцова Т.Н., Егоров Ц.А., Коростылева Т.В., Козловская Г.В., Пухальский В.А. Исследование генома культурных растений и их сородичей применительно к генетической теории селекции: исследование спектров дефензинов у устойчивых и восприимчивых к фитопатогенам видов пшеницы. Биоразнообразие и динамика генофондов. Подпрограмма II «Динамика генофондов». Рос. акад. наук. - М., 2007. - С. 139-141.

Поморцев А.А., Бугрий О.В., Нецветаев В.П., Пухальский В.А. Компонентный состав гордеина и соотношение фракций белка зерна ячменя. Доклады ВАСХНИЛ. 1990. № 5. С. 13-18.

Поморцев А.А., Животовский Л.А., Калабушкин Б.А., Лялина Е.В., Пухальский В.А. Оценка максимальной частоты «чужих» биотипов в популяции с учетом априорных данных. Экология. 2005. № 2. С. 106-109.

Поморцев А.А., Животовский Л.А., Калабушкин Б.А., Пухальский В.А. Электрофорез запасных белков как метод сортового контроля у ярового ячменя. Селекция и семеноводство. 2004. № 3. С. 20-28.

Поморцев А.А., Мартынов С.П., Лялина Е.В., Пухальский В.А. Кластерная структура популяций ячменя (Hordeum vulgare L.) по гордеин-кодирующим локусам в странах Передней Азии, Северной и Северо-Восточной Африки, Ближнего Востока и Южной Аравии. Генетика. 2013. Т. 49. № 10. С. 1190-1201.

Поморцев А.А., Терещенко Н.А., Лялина Е.В., Офицеров М.В., Пухальский В.А. Хромосомная локализация гена устойчивости к пыльной головне Run8 у ячменя. Генетика. 1998. Т. 34. № 11. С. 1513-1517.

Поморцев А.А., Терещенко Н.А., Офицеров М.В., Пухальский В.А. Хромосомная локализация гена устойчивости к пыльной головне Run 6 у ячменя. Генетика. 1999. Т. 35. № 7. С. 1016-1018.

Пухальский А.В., Пухальский В.А. К 100-летию научной селекции растений в России. Селекция и семеноводство. 2003. № 2. С. 16-32.

Пухальский А.В., Удачин Р.А., Пухальский В.А. Основатель отечественной тритикологии (к 120-летию со дня рождения профессора К.А. Фляксбергера). Селекция и семеноводство. 2000. № 2. С. 26-33.

Пухальский В.А. Влияние продолжительности освещения, интенсивности и спектрального состава света на рост и развитие озимой твердой пшеницы. Доклады ТСХА. 1961. Вып. 72. С. 65-72.

Пухальский В.А. Формирование генеративных органов у новых форм озимых твердых пшениц в условиях различных световых режимов. Доклады ТСХА. 1961. Вып. 62. С. 133-142.

Пухальский В.А. Стадийное развитие озимых твердых пшениц. Доклады ТСХА. 1962. Вып. 77. С. 85-93.

Пухальский В.А. Биология и морфогенез новых форм озимой твердой пшеницы. автореферат дис. ... канд. сельскохозяйственных наук. - М.: Московская ордена Ленина сельскохозяйственная академия имени К.А. Тимирязева, 1963.

Пухальский В.А. Ботаническое описание новых форм озимых твердых пшениц. Доклады ТСХА. 1963. Вып. 88. С. 231-233.
Пухальский В.А. Развитие и рост озимой твердой пшеницы Triticum durum Desf. в условиях различного спектрального состава в зависимости от продолжительности фотопериода. Экспериментальный морфогенез. 1963. МГУ. Т. 1. С. 137-144.

Пухальский В.А. Стадия яровизации и световая стадия у озимых твердых пшениц. Доклады ТСХА. 1964. Вып. 98. С. 243-249.

Пухальский В.А. Влияние светового режима на развитие и рост озимых твердых пшениц. Известия ТСХА. 1965. № 4. С 114-126.

Пухальский В.А. Влияние сроков осеннего сева на ход формирования генеративных и вегетативных органов у озимых пшениц. Доклады ТСХА. 1965. Вып. 102.

Пухальский В.А. Книга о биологическом контроле за развитием и ростом растений. Вестник сельскохозяйственной науки. 1965. № 1. С. 152-153.

Пухальский В.А. Новые формы озимой твердой пшеницы. Селекция и семеноводство. 1965. № 6. С. 40-43.

Пухальский В.А. Стадия яровизации у твердой пшеницы (T. durum) при различных световых режимах. Доклады ТСХА. 1965. Вып. 113. С. 107-109.

Пухальский В.А. Селекционная ценность новых форм озимых твердых пшениц: Сб. «Говорят молодые ученые». - М.: Московский рабочий, 1966. - С. 114-118.

Пухальский В.А. Список генов кукурузы. Сельское хозяйство за рубежом. 1971. № 3. С. 14-19.

Пухальский В.А. Изучение некоторых мутантов твердых пшениц (T. durum Desf.) на наличие в генотипах генов гибридного некроза. Доклады TCXA. 1972. Вып. 187. С. 73-74.

Пухальский В.А. Распространение генов гибридного некроза яровых и озимых сортов мягких пшениц СССР. Известия ТСХА. 1972. Вып. 6. С. $73-$ 79.

Пухальский В.А. К проблеме гибридного некроза в генетике пшеницы. Доклады ТСХА. 1974. В. 204. С. 119-122.

Пухальский В.А. Генетические основы гибридного некроза. Известия ТСХА. 1975. Вып. 2. С. 75-83.

Пухальский В.А. Географическое распространение генов гибридного некроза по территории СССР. Вестник сельскохозяйственной науки. 1975. № 8. С. 49-56.

Пухальский В.А. Локализация генов гибридного некроза в сортах пшеницы СССР в зависимости от образа жизни. Доклады ТСХА. 1975. Вып. 209. С. 75-79.

Пухальский В.А. Генетика некрозного треугольника. Доклады ТСХА. 1976. Вып. 224. Ч. 2. С. 56-60.

Пухальский В.А. Локализация генов гибридного некроза в генотипах современных и стародавних сортов мягкой пшеницы СССР. Труды Арм. НИИЗ, сер. Пшеница, Эчмиадзин. 1976. № 1. С. 31-41.

Пухальский В.А. Некоторые вопросы генетики гибридного некроза. Труды Арм.НИИЗ, сер. Пшеница, Эчмиадзин. 1976. № 2. С. 81-86.

Пухальский В.А. Влияние условий произрастания на экспрессивность генов гибридного некроза. Доклады ВАСХНИЛ. 1977. № 9. С. 17-18.

Пухальский В.А. Гены гибридного некроза и некоторые вопросы генетической теории селекции: Сб. «Актуальные вопросы селекции и семеноводства полевых культур ТСХА». - М., 1978. - С. 82-86.

Пухальский В.А. Исследование генетических систем, вызывающих летальность в роде Friticum L., применительно к генетической теории селекции: автореф. дис. ... д-ра биол. наук: 03.00.15. - М., 1981. - 53 с.

Пухальский В.А. Предисловие к русскому изданию кн. К.С. Гилла «Карликовые пшеницы» (пер. с английского). - М.: Колос, 1984. - С. 3-4.

Пухальский В.А. Число генов окраски зерна у сортов яровой мягкой пшеницы (T. aestivum L.). Генетика. 1984. Т. 20. № 3. С. 457-462.

Пухальский В.А. Генетика - селекционерам. Нечерноземье. 1989. № 6. С. 41-42.

Пухальский В.А. К разработке системного подхода в определении генов, детерминирующих количественные и качественные признаки. Сельскохозяйственная биология (сер. Биология растений). 1992. № 1. С. 17-22.

Пухальский В.А. Обоснование подхода к изучению геногеографии у пшеницы и ячменя [Использование маркерных генов]. Генетика. 1994. Т. 30 (Приложение). С. 129.

Пухальский В.А. Материалы к изучению генов гибридного некроза в роде Triticum L. Генетика. 1996. T. 32. № 4. С. 541-546.

Пухальский В.А. Использование молекулярно-генетических подходов при изучении устойчивости растений к фитопатогенам. Типы устойчивости растений к болезням (материалы научного семинара). - СПб., 2003. С. 10-16.

Пухальский В.А. Проблемы генетической теории селекции. Информационный вестник ВОГИС. 2005. Т. 9. № 3. С. 306-316. 
Пухальский В.А., Аникеева Н.Ф., Данаилов Ж.П., Косарева Г.А. К познанию гибридной карликовости у пшеницы. Вестник сельскохозяйственной науки. 1982. № 1. С. 52-61.

Пухальский В.А., Билинская Е.Н., Иорданская И.В. Распределение генов гибридного некроза у сортов и линий яровой мягкой пшеницы [Изучение сортов селекции СибНИИСХ]. Селекция и семеноводство. 1998. № 2. С. 13-18.

Пухальский В.А., Билинская Е.Н. Идентификация генов гибридного некроза у сортов озимой мягкой пшеницы (T. aestivum L.). Генетика. 1998. T. 34, № 12. С. 1639-1647.

Пухальский В.А., Билинская Е.Н. Некротические генотипы современных сортов яровой мягкой пшеницы (T. aestivum L.) России, Украины, Белоруссии и Казахстана. Генетика. 1997. Т. 33. № 11. С. 1523-1528.

Пухальский В.А., Билинская Е.Н. Новые данные по изучению генов гибридного некроза сортообразцов вида T. dicoccum (Scbrank) Schnell. Генетика. 1999. Т. 35. № 10. С. 1390-1395.

Пухальский В.А., Билинская Е.Н., Кудрявцев А.М. Мониторинг отягощенности геномов сортов озимой мягкой пшеницы (Triticum aestivum L.) генами гибридного некроза. Генетика. 2018. Т. 54. № 12. С. 1466-1472.

Пухальский В.А., Билинская Е.Н., Мартынов С.П., Добротворская Т.В., Оболенкова Л.А. Новые данные по распространению генов гибридного некроза в сортах озимой мягкой пшеницы (Triticum aetivum L). Генетика. 2008. Т. 44. № 2. С. 209-218.

Пухальский В.А., Билинская Е.Н., Мартынов С.П., Оболенкова Л.А. Исследование генома культурных растений и их сородичей применительно к генетической теории селекции: анализ наличия генов гибридной летальности в геномах современных сортов озимой мягкой пшеницы Чехии. Динамика генофондов. - М., 2007. - С. 151-153.

Пухальский В.А., Вареница Е.Т. Семеноводство зерновых культур в Италии. Селекция и семеноводство. 1966. № 6. С. 33-58.

Пухальский В.А., Вьюгина Г.В. Исследование некротических гибридов мягкой яровой пшеницы в первом и втором гибридных поколениях. Известия ТСХА. 1978. Вып. 6. С. 56-62.

Пухальский В.А., Вьюгина Г.В. Содержание каратиноидов в листьях некротических гибридов яровой мягкой пшеницы. Сельскохозяйственная биология. 1983. № 6. С. 81-82.

Пухальский В.А., Гинс В.К., Пискунова Н.П. Генетическая детерминация признака фотохимической активности хлоропластов листьев яровой пшеницы. Доклады ВАСХНИЛ. 1984. № 7. С. 2-4.

Пухальский В.А., Данаилов Ж.П. Влияние генов гибридного некроза на проявление гетерозиса в F1 у гибридов мягкой яровой пшеницы. Доклады ТСХА. 1972. Вып. 180. Ч. 11. С. 109-112.

Пухальский В.А., Данаилов Ж.П. К вопросу о продуктивности F2 гибридов пшеницы, проявивших в F1 депрессию под влиянием комплементарных генов некроза. Доклады ТСХА. 1972. Вып. 182. С. 169-173.

Пухальский В.А., Дикарев В.Г. Изучение развития зародыша и эндосперма у яровой мягкой пшеницы. Известия ТСХА. 1975. Вып. 4. С. 60-67.

Пухальский В.А., Дикарев В.Г., Новиков Н.Н. Электрофоретическое изучение легкорастворимых белков зерна нормальных и некротических гибридов яровой мягкой пшеницы и их родительских форм. Известия ТСХА. 1976. Вып. 6. С. 70-80.

Пухальский В.А., Зуев Е.В., Билинская Е.Н., Кудрявцев А.М. Распространение аллелей генов гибридного некроза в генотипах аборигенных сортов мягкой пшеницы (Triticum aestivum L.) Ирана, Афганистана, Палестины и Трансиордании. Генетика. 2019. Т. 55. № 8. С. 904-911.

Пухальский В.А., Иванова С.В., Ронис Н.Б. Лапочкина И.Ф. Расщепление по числу хромосом у межвидовых гибридов пшеницы. Известия ТСХА. 1983. Вып. 4. С. 59-63.

Пухальский В.А., Иванова С.В., Ронис Н.Б. О хромосомном расщеплении в популяциях второго поколения межвидовых гибридов пшеницы T. aestivum x T. durum. Известия ТСХА. Вып. 4. 1980. С. 49-55.

Пухальский В.А., Иорданская И.В., Бадаева Е.Д., Лапочкина И.Ф., Билинская Е.Н. Генетический анализ признака «отсутствие воскового налета на колосе» у линии мягкой пшеницы. Генетика. 1999. Т. 35. № 9. С. 1223-1227.

Пухальский В.А., Козленко Л.В. Влияние генов некроза на проявление депрессии у гибридов первого поколения при межсортовых скрещиваниях пшеницы. Генетика. 1970. Т. 6. № 9. С. 16-21.

Пухальский В.А., Козленко Л.В. Гибридный некроз у пшеницы. Сельскохозяйственная биология. 1969. № 1. Т. 4. С. 44-50.

Пухальский В.А., Козленко Л.В. Комбинационная ценность сортов яровой мягкой пшеницы. Вестник сельскохозяйственной науки. 1971. № 8 . C. 47-54.
Пухальский В.А., Козленко Л.В., Аникеева Н.Ф. Закономерности наследования массы одной гибридной зерновки: Сб. «Совершенствование селекционно-генетического и семеноводческого процессов зерновых и зернобобовых культур в Нечерноземье». - М., 1988. - С. 74-85.

Пухальский В.А., Косарева Г.А. Влияние комплементации генов гибридного некроза на количественные признаки в первом поколении гибридов яровой мягкой пшеницы. Известия ТСХА. 1978. Вып. 3. С. 67-79.

Пухальский В.А., Косарева Г.А. Локализация генов гибридного некроза в сортах яровой пшеницы различных экологических групп. Известия ТСХА. 1976. Вып. 5. С. 58-63.

Пухальский В.А., Косарева Г.А. Материалы к изучению гибридной карликовости у яровой пшеницы. Доклады ТСХА. 1975. Вып. 214. С. 55-89.

Пухальский В.А., Косарева Г.А. О генетике гибридного некроза. Вестник сельскохозяйственной науки. 1978. № 7. С. 26-33.

Пухальский В.А., Куравамвели Д.С., Новиков Н.Н. Взаимосвязь дозы генома D и состава белков в эндосперме мягкой пшеницы. Доклады BACXНИЛ. 1980. № 10. С. 8-10.

Пухальский В.А., Лапочкина И.Ф. Влияние генотипа на некоторые закономерности отдаленной гибридизации: Сб. тез. докл. «Роль отдаленной гибридизации в эволюции и селекции пшеницы». - Тбилиси: ГрузСХИ, 1985. - С. 37-38.

Пухальский В.А., Лапочкина И.Ф. Межвидовая гибридизация в роде Triticum L. с участием естественной и искусственной спельты. Известия ТСХА. Вып. 5. 1980. С. 33-44.

Пухальский В.А., Латыпова Г.А., Лызлов Е.В. Генетическая дивергенция сортов овса. Доклады ВАСХНИЛ. № 4. 1990. С. 13-16.

Пухальский В.А., Максимов И.Л. Гистохимическая характеристика генеративных органов озимой мягкой и твердой пшеницы. Доклады ТСХА. 1966. Вып. 122. С. 107-109.

Пухальский В.А., Максимов И.Л. Морфологическая изменчивость у сорта озимой твердой пшеницы Мичуринка. Доклады ТСХА. 1965. Вып. 108. С. 243-246.

Пухальский В.А., Максимов И.Л. Случаи спонтанной гибридизации у озимой твердой пшеницы. Известия ТСХА. 1967. Вып. 4. С. 92-101.

Пухальский В.А., Мальченко В.В., Кызласов В.Г., Руденко М.И., Латыпов А.З., Иорданская И.В., Марченко Н.В. Проявление гетерозиса у пшеницы и ячменя в системе диаллельных скрещиваний. Генетика. Т. 25. № 3. 1989. С. 487-497.

Пухальский В.А., Мартынов С.П., Билинская Е.Н. Динамика генов гибридного некроза в сортах озимой мягкой пшеницы (Triticum aestivum L.) pocсийской селекции. Генетика. 2010. Т. 46. № 11. С. 1516-1524.

Пухальский В.А., Могутова О.Б., Руденко М.И. Генные взаимодействия в гибридных популяциях ярового ячменя, полученных на основе доноров высоколизиновости. Доклады ВАСХНИЛ. 1986. № 7. С. 9-12.

Пухальский В.А., Могутова О.Б., Руденко М.И., Ли Л.М. Наследование массы 1000 зерен и содержание лизина в зерне гибридами ячменя с участием высоколизиновых доноров: Сб. «Селекционно-генетические исследования зерновых, зернобобовых культур в Центральном районене Нечерноземья». - М.: НИИСХЦРН3, 1985. - С. 33-40.

Пухальский В.А., Одинцова Т.И., Извекова Л.И., Андреева Э.Н., Коростылева Т.В., Истомина Е.А., Славохотова А.А., Шиян А.Н., Козловская Г.В., Оболенкова Л.А., Бадаева Е.Д., Билинская Е.Н. Проблемы естественного и приобретенного иммунитета растений. К развитию идей Н.И. Вавилова. Информационный вестник ВОГИС. 2007. Т. 11. № 3-4. С. 631-649.

Пухальский В.А., Поморцев А.А., Драгович А.Ю., Одинцова Т.И., Упелниек В.П., Кудрявцев В.М., Хадеева Н.В., Ратькин А.В., Оболенкова Л.А., Горюнова С.В.Исследование генома культурных растений и их сородичей применительно к генетической теории селекции. Динамика генофондов растений, животных и человека. - М., 2005.

Пухальский В.А., Ронис Н.Б. О влиянии качества пыльцы на завязываемость зерен у пшеницы при парных скрещиваниях. Доклады TCXА. 1966. Вып. 126. С. 69-72.

Пухальский В.А., Ронис Н.Б. О физиологических предпосылках селективного оплодотворения у пшеницы. Сельскохозяйственная биология. 1973. № 4. С. 503-506.

Пухальский В.А., Ронис Н.Б. Селективное оплодотворение у пшеницы. Сельскохозяйственная биология. 1970. № 3. С. 438-440.

Пухальский В.А., Ронис Н.Б. Селективное оплодотворение у пшеницы. Доклады ТСХА. 1969. Вып. 152.

Пухальский В.А., Ронис Н.Б., Аникеева Н.Ф. О селективном оплодотворении у пшеницы. Селекция и семеноводство. 1978. № 3. С. 18-20.

Пухальский В.А., Ронис Н.Б., Иванова С.В. Особенности мейоза у яровой пшеницы Московская 21. Селекция и семеноводство. № 7. 1980. С. 13-14. 
Пухальский В.А., Руденко М.И. Использование метода ОСП в проработке гибридных популяций ярового ячменя: Сб. «Селекционно-генетические исследования зерновых, зернобобовых культур в Центральном районе Нечерноземья». - М.: НИИСХЦРНЗ, 1985. - С. 40-47.

Пухальский В.А., Рыбакова М.И., Иорданская И.В. Селективное наследование некротических генотипов у озимой мягкой пшеницы. Доклады Россельхозакадемии. 1998. № 1. С. 3-4.

Пухальский В.А., Смирнов.С.П., Коростылева Т.В., Билинская Е.Н., Елисеева А.А. Генетическая трансформация пшеницы (Triticum aestivum L.) с помощьюAgrobacteriumtumefaciens.Генетика. 1996.Т.32.№11.С.1596-1600.

Пухальский В.А., Уколов А.А. Зависимость зимостойкости новых форм озимой твердой пшеницы от накопления сахаров в осенний период. Доклады ТСХА. 1963. Вып. 93. С. 53-56.

Пухальский В.А., Уколов А.А. Зависимость зимостойкости озимых твердых пшениц от накопления сахаров в осенний период. Вестник сельскохозяйственной науки. 1965. С. 113-117.

Пухальский В.А., Ячевская Г.Л., Довнар Т.И., Волкова Г.А. Интрогрессия чужеродных генов, определяющих ценные признаки, в геном T. aestivum с использованием облучения пыльцы. Всесоюзный радиобиологический съезд. - Пущино, 1989. - С. 641.

Размалогов В.П., Пухальский В.А. Культура пыльцевых зерен T. aestivum L. in vitro. Доклады АН СССР. 1979. Т. 244. № 5. С. 1278-1280.

Размологов В.П., Пухальский В.А. Культура пыльников Triticum aestivum L. in vitro. Бюл. Гл. Бот. Сада АН СССР. 1982. Вып. 123. С. 64-68.

Ремесло В.Н., Пухальский В.А. Межсортовая гибридизация озимой пшеницы при свободном ветроопылении. Агробиология. 1961. № 2. С. 169-176.

Рожнова Н.А., Геращенков Г.А., Одинцова Т.И., Мусин С.М., Пухальский В.А. Синтез новых белков картофеля in vitro при защитном действии арахидоновой кислотой в процессе развития вирусных инфекций. Физиология растений. 2001. Т. 48. № 6. С. 897-905.

Руденко М.И., Алексеева И.Ю., Пухальский В.А. Оценка селекционной ценности сортов и гибридов ярового ячменя. Принципы и методы селекции и семеноводства зерновых и зернобобовых культур в Нечерноземье (25 лет Московскому селекцентру). - М., 1996. - С. 51-57.

Славохотова А.А, Андреева Э.Н., Шиян А.Н., Одинцова Т.И., Пухальский В.А. Исследование генома культурных растений и их сородичей применительно к генетической теории селекции: исследование первичных структур геномов вакцинного и патогенных штаммов зеленой крапчатой мозаики огурца. Динамика генофондов. - М., 2007.

Славохотова А.А., Андреева Э.Н., Шиян А.Н., Одинцова Т.И., Пухальский В.А. Особенности генов белка оболочки российских штаммов вируса зеленой крапчатой мозаики огурца. Генетика. 2007. Т. 43. № 11. С. 1461-1467.

Славохотова А.А., Истомина Е.А., Андреева Э.Н., Шиян А.Н., Одинцова Т.И., Пухальский В.А. Исследование генома культурных растений и их сородичей применительно к генетической теории селекции: изучение динамики накопления белков оболочки аттенуированных и патогенных штаммов табамовирусов в растениях-хозяевах. Динамика генофондов. - М., 2008. - С. 192-197.

Слезина М.П., Коростылева Т.В., Славохотова А.А., Истомина Е.А., Щербакова Л.А., Пухальский В.А., Одинцова Т.И. Гены гевеиноподобных анти микробных пептидов пырея Elytrigia repens (L.) Desv. ex Nevski. Генетика. 2018. T. 54. № 10. С. 1136-1144.

Смирнов С.П., Крашенинникова Л.В., Пухальский В.А. Устойчивость к вирусу табачной мозаики у трансгенных растений табака, индуцирующих альфа-интерферон человека. Доклады АН СССР. 1991. Т. 317. № 3. С. 732-734.

Смирнов С.П., Крашенинникова Л.В., Пухальский В.А. Эффект синтеза молекул двунитевой РНК в трансгенных растениях табака на устойчивость к вирусу табачной мозаики. Доклады АН СССР. 1993. Т. 331. № 2. C. $241-245$.

Смирнов С.П., Крашенинникова Л.В., Теверовская Э.Х., Пухальский В.А. Создание экспрессивного интегративного вектора и его использование для введения в растения гена рекомбинантного альфа-интерферона человека. Генетика. 1990. Т. 26. № 12. С. 2101-2121.

Смирнов С.П., Пухальский В.А. Родственные вирусу табачной мозаики молекулы нуклеиновых кислот, присутствующие в здоровых растениях табака. Доклады АН СССР. 1991. Т. 320. № 5. С. 1254-1257.

Уколов А.А., Пухальский В.А. История и селекция озимой твердой пшеницы в СССР. Известия ТСХА. 1964. № 2. С. 95-107.

Уколов А.А., Пухальский В.А. Особенности формирования генеративных и вегетативных органов у новых форм озимой твердой пшеницы. Известия TСXА. 1964. № 3. С. 23-33.
Уколов А.А., Пухальский В.А. Петр Иванович Лисицын (к 100-летию со дня рождения). Селекция и семеноводство. 1977. № 1. С. 22-23.

Уколов А.А., Пухальский В.А. Работы Тимирязевской сельскохозяйственной академии по созданию сортов твердой озимой пшеницы. Вестник сельскохозяйственной науки. 1962. №7. С. 54-63.

Уколов А.А., Пухальский В.А. Стадийное развитие озимых твердых пшениц. Агробиология. 1964. № 6. С. 879-888.

Уколов А.А., Пухальский В.А., Максимов И.Л. Завязывание зерен у твердой озимой пшеницы при различных способах опыления. Доклады ТСXА. 1965. Вып. 108. С. 237-242.

Уткина Л.Л., Жабон Е.О., Славохотова А.А., Рогожин Е.А., Шиян А.Н., Гришин Е.В., Егоров Ц.А., Одинцова Т.И., Пухальский В.А. Гетерологичная экспрессия синтетического гена нового гевеиноподобного пептида Leymus arenarius в клетках Eschrichia coli. Генетика. 2010. Т. 46, № 12. C. $1645-1651$.

Фетисов А.В., Одинцова Т.И., Извекова Л.И., Пухальский В.А. Белки листьев огурца при вирусной инфекции. Известия АН СССР (Серия биол.). 1991. T. 4. С. 619-624.

Хадеева Н.В., Легкобит М.П., Хуссейн И.А., Яковлева Е.Ю., Пухальский В.А. Размножение клубнеобразующих видов стахиса (Stachys sieboldii и S. palustris) посредством индукции микроклубней in vitro. Нетрадиционные сельскохозяйственные лекарственные и декоративные растения. 2006. № 1 (3).

Шелухина О.Ю., Бадаева Е.Д., Брежнева Т.А., Лоскутов И.Г., Пухальский В.А. Сравнительное исследование диплоидных видов рода Avena L. C использованием цитогенетических и биохимических маркеров: A. pilosa M.B. и A. clauda Dur. Генетика. 2008. T. 44. № 9. С. 1246-1251.

Шелухина О.Ю., Бадаева Е.Д., Брежнева Т.А., Лоскутов И.Г., Пухальский В.А. Сравнительное исследование диплоидных видов рода Avena L. с использованием цитогенетических и биохимических маркеров: Avena canariensis Baum et Fedak и A. longiglumis Dur. Генетика. 2008. T. 44. № 6. C. 798-806.

Шелухина О.Ю., Бадаева Е.Д., Лоскутов И.Г., Пухальский В.А. Сравнительное цитогенетическое исследование тетраплоидных видов овса с AC-геномным составом: Avena insularis, A. magna и A. murphyi. Генетика. 2007. T. 43. № 6. С. 747-761.

Шиян А.Н., Мильшина Н.В., Снегирева П.Б., Пухальский В.А. Изучение первичной структуры вакцинного штамма вируса табачной мозаики V-69. Генетика. 1994. Т. 30. № 12. С. 1626-1629.

Ячевская Г.Л., Кызласов В.Г., Мальченко В.В., Руденко М.И., Пухальский В.А., Иорданская И.В., Федорова Т.Н., Макарова И.Ю., Алексеева И., Лапочкина И.Ф. Ретроспективный взгляд на использование методов и подходов к созданию и оценке исходного материала в лаборатории генетики и цитологии (1966-1995) [Селекционно-генетические исследования зерновых культур и их сородичей]. Принципы и методы селекции и семеноводства зерновых и зернобобовых культур в Нечерноземье (25 лет Московскому селекцентру). - М., 1996. - С. 208-214.

Ячевская Г.Л., Пухальский В.А., Довнар Т.И., Волкова Г.А. Неоцентрическая активность у пшенично-пырейных гибридов. Известия СО АН СССР. 1990. Вып. 2. С. 18.

Ячевская Г.Л., Пухальский В.А., Довнар Т.И., Волкова Г.А. Цитогенетические основы получения добавленных и замещенных линий пшеницы: Сб. «Современные методы изучения структур и функций биологических систем». - М., 1988. - С. 35-37.

Ячевская Г.Л., Пухальский В.А., Лапочкина И.Ф., Довнар Т.И., Волкова Г.А. Цитогенетическая характеристика пшенично-пырейных и пшеничноэгилопсовых гибридов F1 и F2BC1: Сб. «Селекция зерновых культур на стабильность урожайности, иммунитета и качество зерна в Нечерноземной зоне». - М., 1986. - С. 156-167.

Badaeva E., Shelukhina O.Y., Goryunova S., Loskutov I., Pukhalskiy V. Phylogenetic relationships of tetraploid AB-genome Avena species evaluated by means of cytogenetic (C-banding and FISH) and RAPD analyses. Journal Botany. 2010. V. 2010.

Badaeva E.D., Kellwagen J., Knupffer H., Wasserman L., Dedkova O.S., Mitrofanova O., Kovaleva O., Liapanova O., Pukhalskiy V.A., Osakan H., Graner A., Willcocx G., Kilian B. Chromosomal Passports Provide New Insighes into Diffusion of Emmer Wheat. PLOS ONE. May 29. 2015. P. 1-25. DOI: 10.1371/joumal.Pone.0128556.

Badaeva E.D., Shelukhina O.Y., Pukhalskiy V.A., Diederichsen A., Loskutov I.G. Comparative cytogenetic analysis of Avena macrostachya and diploid C-genome Avena species. Genome. 2010. V. 53. No. 2. P. 125-137. 
Bagnara D., Poukhalski V., Rossi L. Eredita, del peso delle cariossidi in cultivar e linee mutanti di frumento duro. Genetica Agraria. 1972. V. 26. No. 3-4. P. 247-277.

Egorov T.A., Grishin E.V., Odintsova T.I., Pukhalsky V.A. Diversity of wheat antimicrobial peptides. Peptides. 2005. V. 26. No. 11. P. 2064-2073.

Lapochkina I.F., Solomatin D.A, Pukhalskiy V.A. Introgression of resistance genes to powdery mildew and brown rest from Aegilops speltoides Tausch. in to common wheat genome upon hybridization and using pollen irradiation. Plant Science (Sofia). 1994. V. 31. No. 7. P. 47-51.

Odintsova T.I., Korostyleva T.V., Pukhalsky V.A., Grishin E.V., Egorov T.A., Odintsova M.S. Analysis of Triticum boeoticum and Triticum urartu seed defensins: to the problem of the origin of polyploid wheat genomes. Biochimie. 2008. V. 90. No. 6. P. 939-946.

Odintsova T.I., Kudryavtsev A.M., Pukhalsky V.A., Rogozhin E.A., Sklyar I.V., Musolyamov A.K., Grishin E.V., Egorov T.A., Smirnov A.N. Antifungal activity of storage $2 \mathrm{~s}$ albumins from seeds of the invasive weed dandelion Taraxacum officinale Wigg. Protein Peptide Letters. 2010. T. 17. No. 4. P. 522529.

Odintsova T.I., Pukhalsky V.A., Egorov T.A., Musolyamov A.Kh., Grishin E.V., Odintsova M.S. Seed defensins from T. kiharae and related species: genome localization of defensin-encoding genes. Biochimie. 2007. T. 89. No. 5. P. 605-612.

Odintsova T.I., Slavokhotova A.A., Khadeeva N.V., Korostyleva T.V., Pukhalsky V.A., Vassilevski A.A., Musolyamov A.K., Finkina E.I., Rogozhin E.A., Grishin E.V., Egorov T.A. A novel antifungal hevein-type peptide from Triticum kiharae seeds with a unique 10-cysteine motif. FEBS Journal. 2009. V. 276. No. 15. P. 4266-4275.

Osipova E.V., Balakhnina V.P., Rudenko M.I., Pukhalskiy V.A. The selection of homozygous lines of barley resistant to Heterodera filipjevi based on the nematode resistant turkish k-6808 cultivar. Russian Journal Nematology. 1997. V. 5. No. 1. P. 23-26.

Pukhalskiy V.A, Odintsova T.I., Izvekova L.I., Andreeva E.N., Fetisov A.V., Shiyan A.N., Snegireva P.B. Study of thenature of virus pathogenicity and mechanisms of induced plant resistance in the system cucumber-CGMMV and tomato-TMV. Plant Science (Sofia). 1994. V. 31. No. 7. P. 248-251.

Pukhalskiy V.A. Analysis of necrotic genotypes in Triticum aestivum L. cultivars produced in the former USSR republics. Annual Wheat Newsletter. 1997. V. 43. P. 202.
Pukhalskiy V.A., Bilinskaya E.N. Distribution of hybrid necrosis genes in winter wheat genotypes. Annual Wheat Newsletter. 1998. V. 44. P. 191.

Pukhalskiy V.A., Bilinskaya E.N. Genotype analysis of a Spring-type cultivars of common wheat carrying the Lr13 gene for the presence of the Ne2m gene. Annual Wheat Newsletter. 2018. V. 64. P. 36-37.

Pukhalskiy V.A., Bilinskaya E.N., Martinov S.P., Obolenkova L.A. Hybrid necrosis genes in modern cultivars of winter common wheat of the Czech Republic. Annual Wheat Newsletter. 2007. V. 53. P. 82.

Pukhalskiy V.A., Bilinskaya E.N., Udachin R.A. Hybrid necrosis genes in aboriginal wheats of middle asia in the light of the problem of the primary centers of biodiversity of the Triticum L. genus. Euphytica. 2009. V. 165. No. 3. P. 533-543.

Pukhalskiy V.A., Martynov S.P., Dobrotvorskaya T.V. Analysis of geographical and breeding-related distribution of hybrid necrosis genes in bread wheat (Triticum aestivum L.). Euphytica. 2000. V. 114. No. 3. P. 233-240.

Pukhalsky V.A. Winter durum wheat in the USSR. Triticum, nev. series Sydney. 1964. No. 7. P. 14-15.

Slavokhotova A.A., Istomina E.A., Andreeva E.N., Korostyleva T.V., Pukhalskiy V.A., Shijan A.N., Odintsova T.I. An attenuated strain of cucumber green mottle mosaic virus as a biological control agent against pathogenic viral strains. American Journal Plant Scie. 2016. V. 7. P. 724-732.

\section{Список литературы / References}

Шумный В.К., Гончаров П.Л. Памяти академика РАСХН Анатолия Васильевича Пухальского (16.07.1909-28.02.2008). Информационный вестник ВОГИС. 2008;12(1-2):262-267.

Shumny V.K., Goncharov P.L. In memoriam: Academician of the Russian Academy of Agricultural Sciences Anatoliy V. Pukhalskiy (July 16, 1909 February 28, 2008). Herald Vavilov Society Geneticists Breeding Scientists. 2008;12(1-2):262-267 (in Russian).

Конфликт интересов. Авторы заявляют об отсутствии конфликта интересов.

Для цитирования. Гончаров Н.П., Карлов Г.И., Кудрявцев А.М., Упелниек В.П., Соловьев А.А. Виталий Анатольевич Пухальский: к 85-летию со дня рождения. Письма в Вавиловский журнал генетики и селекции. 2019;5(1):44-55. DOI 10.18699/Letters2019-5-5.

For citation. Goncharov N.P., Karlov G.I., Kudryavtsev A.M., Upelniek V.P., Soloviev A.A. On the 85th anniversary of Vitaliy A. Pukhalskiy. Pisma v Vavilovskii Zhurnal Genetiki i Selektsii = Letters to Vavilov Journal of Genetics and Breeding. 2019;5(1):44-55. DOI 10.18699/Letters2019-5-5. (in Russian)

Поступила в редакцию 02.11.2019. После доработки 07.11.2019. Принята к публикации 07.11.2019. 